\title{
Sea Anemones (Cnidaria: Actiniaria and Corallimorpharia) from Panama
}

\author{
Anémonas de mar (Cnidaria: Actiniaria y Corallimorpharia) de Panamá \\ Agustín Garese ${ }^{1,2}$, Héctor M. Guzmán³ and Fabián H. Acuña ${ }^{1,2}$ \\ ${ }^{1}$ Departamento de Ciencias Marinas, Facultad de Ciencias Exactas y Naturales, Universidad Nacional de \\ Mar del Plata. Funes 3250, 7600 Mar del Plata, Argentina \\ ${ }^{2}$ National Council for Scientific and Technical Research of Argentina (CONICET) \\ ${ }^{3}$ Smithsonian Tropical Research Institute, PO Box 0843-03092, \\ Balboa, Ancon, Republic of Panama \\ agarese@mdp.edu.ar
}

\begin{abstract}
Resumen.- A partir de la literatura existente se realizó una lista actualizada y revisada de las anémonas de mar de ambas costas de Panamá, que incluyó 26 especies válidas (22 pertenecientes al orden Actiniaria, tres al orden Corallimorpharia y una especie de ubicación sistemática incierta). La especie Calliactis polypus es un registro nuevo para esta región. Siete de las especies se conocen solamente en Panamá. La riqueza de especies es predominante en el Golfo de Panamá, debido probablemente a un esfuerzo de muestreo mayor y desproporcionado en relación a otras zonas. El hecho
\end{abstract}

\section{Introduction}

The Pacific and Caribbean coasts of the Republic of Panama are $1,700 \mathrm{~km}$ and 1,287 km long, respectively, and the islands, islets, and cays that lie over the continental shelf are home to a rich marine biodiversity. The sea anemones (the common name for cnidarians belonging to the orders Actiniaria and Corallimorpharia) from the coasts of Panama have been poorly studied, and most records date from the nineteenth and early twentieth centuries (Fautin 2008). The first records of sea anemones from the Pacific coast were made by Verrill $(1869,1870)$. He described 11 species of actiniarians, all of them recorded from the Gulf of Panama (mainly in Panama Bay). McMurrich (1893) added a record for Paractis lineolata [valid name Antiparactis lineolatus (Couthouy in Dana, 1846)] from the Gulf of Panama. Other authors have named other species with distributions along the Pacific coast of Panama [e.g. Torrey (1906) for Anthopleura xanthogrammica (Brandt, 1835)].

From the Caribbean coast, Verrill (1869) described the sea anemone species Paractis nobilis. Then, Smith (1973) registered Condylactis gigantea (Weinland, 1860) in symbiosis with a fish in Galeta island while Sebens (1976) is the most recent work referred to sea anemones and there are listed C. gigantea, Bunodosoma granulifera que los registros existentes estén fuertemente sesgados hacia un centro de intenso muestreo, indica la necesidad de muestreos adicionales en otras áreas. Estudios posteriores deberán estar orientados no sólo a la búsqueda de nuevos taxa, sino también a la verificación de las descripciones y el status taxonómico de las especies registradas.

Palabras clave: cnidarios bentónicos, distribución, biodiversidad, América Central

(Le Sueur, 1817), Stoichactis helianthus [now Stichodactyla helianthus (Ellis, 1768)], Lebrunia danae (Duchassaing \& Michelotti, 1860), Phymanthus crucifer (Le Sueur, 1817), Heteractis lucida [now Ragactis lucida (Duchassaing de Fonbressin \& Michelotti, 1860)], Bartholomea annulata (Le Sueur, 1817), Paradiscosoma neglecta [now Discosoma neglecta (Duchassaing \& Michelotti, 1860)], Rhodactis sanctithomae [now Discosoma sanctithomae (Duchassaing \& Michelotti, 1860)] and Ricordea florida (Duchassaing \& Michelotti, 1860). All of them found in front of the coast of Colon city (at the Caribbean end of the Panama Canal). Moreover, McCommas (1991) has recorded $B$. granulifera in the coast of Colon while $S$. helianthus was registered by Dunn (1981). The corallimorpharians $D$. neglecta, D. sanctithomae, and R. florida were also recorded near Colon by Den Hartog (1980). These are the only corallimorpharians recorded for Panama, although Ritson-Williams \& Paul (2007) recently reported one unidentified species of the genus Actinotryx from the archipelago of Bocas del Toro, but this genus is not valid (Fautin 2008). At this place, Guzmán \& Guevara (1998a, 1998b, 1999, 2001) documented the presence of the actiniarian $C$. gigantea, Bartholomea lucida [now Ragactis lucida (Duchassaing de Fonbressin \& Michelotti, 1860)], B. annulata (Le Sueur, 1817), 
Epicystis crucifer [now Phymanthus crucifer (Le Sueur, 1817)] and L. danae, as organisms associated with the coral reefs.

No recent taxonomic studies of the sea anemones of Panama exist. Therefore, the objective of this study was to compile and update the extant information from the literature and to provide an inventory of the sea anemones from both coasts of Panama. We also report a new record for the actiniarian Calliactis polypus (Forsskål, 1775) from the Pacific coast of Panama.

\section{Material and methods}

Taxonomic records, distribution patterns, and information about type localities were extracted from the extant literature. The current classification of sea anemones and the taxonomic status of some species were cross-checked with the electronic database of Fautin (2008).

The identification of $C$. polypus was made by the first author during his stay at the Smithsonian Tropical Research Institute of Panama (STRI) from October to December 2008. Eight specimens of this species were found on October $29^{\text {th }}, 2008$ in Achotines Bay $\left(7^{\circ} 25^{\prime} 4.24^{\prime \prime} \mathrm{N}, 80^{\circ} 10^{\prime} 49.79^{\prime \prime} \mathrm{W}\right)$, which lies on the southeastern tip of the Azuero Peninsula in the pacific littoral of Panama. They were collected from a hermit crab shell at a depth of $2 \mathrm{~m}$ by free diving by the first author during a field trip conducted by the STRI. The specimens were relaxed with $\mathrm{MgCl}_{2}$, then fixed in $5 \%$ formaldehyde and subsequently preserved in ethanol. Seven individuals were dissected and observed under a stereoscopic microscope. Cnidocysts from tentacles, column and acontia were identified using a Zeiss microscope with oil immersion at 1000X magnification. The descriptions of collected specimens agree very well with that provided by Fautin et al. (2007).

\section{Results}

Twenty-six species of sea anemones have been recorded for Panama. Fourteen species all belonging to the Order Actiniaria (sea anemones sensu stricto) and grouped into five families (Table 1), occur along the Pacific Coast. On the Caribbean coast, 11 species (seven Actiniaria within five families, three Corallimorpharia within two families and one with uncertain systematic position) have been identified (Table 2). Some of the species recorded for Panama have been listed with a different name in other publications; these previous names are included in both tables (see also Fautin 2008).

Herein, we provide a new record for Calliactis polypus (Forsskål, 1775) (Fig. 1). This species has a wide distribution (see Table 1) and recently was found in the
Galápagos Islands by Fautin et al. (2007).

At present six species have only been found along the Pacific coast of Panama and all of them are actiniarians. Five species belong to family Sagartiidae: Sagartia panamaensis Verrill, 1869; S. carcinophila Verrill, 1869; S. crispata Verrill, 1869); Actinothoe bradleyi (Verrill, 1869) and Phellia inornata Verrill, 1869; and one species belongs to family Actiniidae: Actinostella ornata Verrill, 1869. The other nine species are distributed in the northeastern Pacific [Actinostella bradleyi (Verrill, 1869); Anthopleura dowii Verrill, 1869; Bunodosoma grandis (Verrill, 1869); Calliactis variegata Verrill, 1869 and Telmatactis panamensis (Verrill, 1869)]. Anthopleura xanthogrammica (Brandt, 1835) is present in the northeastern and northwestern Pacific, the east coast of China, and along the Japanese coast. Antiparactis lineolatus (Couthouy in Dana, 1846) have been mentioned from the southern tip of Chile. Phymactis papillosa (Lesson, 1830) has a wide distribution in the eastern Pacific and has been recorded from Australia and New Zealand. The new record for Panama, Calliactis polypus, is the species with the widest distribution of all sea anemones recorded from Panama (Table 1).

On the Caribbean coast of Panama, Paractis nobilis Verrill, 1869 is the unique species that so far was only described in Panama; it was recorded from the northeastern reef by Verrill. The remaining species are widely distributed in the Caribbean Sea. Bunodosoma granulifera (Le Sueur, 1817) has been recorded for the Caribbean Sea but also for India (Table 2).

\section{Discussion}

The most important previous taxonomic studies of Panamanian sea anemones were carried out by Verrill (1869) and Den Hartog (1980) for the Pacific and the Caribbean coast, respectively; however, comprehensive papers that summarized and verified information were not published. Besides the world-wide sea anemone database (Fautin 2008), this paper represents the first effort to compile all extant information concerning the taxonomy and distribution of sea anemones from Panama.

According with present knowledge, most species cited for the Pacific coast are restricted to the Gulf of Panama, and almost nothing is known about the anemones in other places, such as the Gulf of Chiriquí, where the large marine protected area of Panama, The Coiba National Park, is located. We attribute this disparity of information among different places to the fact that Panama City, with its harbor facilities and scientific institutions, has influenced the intensity of sampling and has biased it mainly to the gulf zone. Records of sea anemones from 


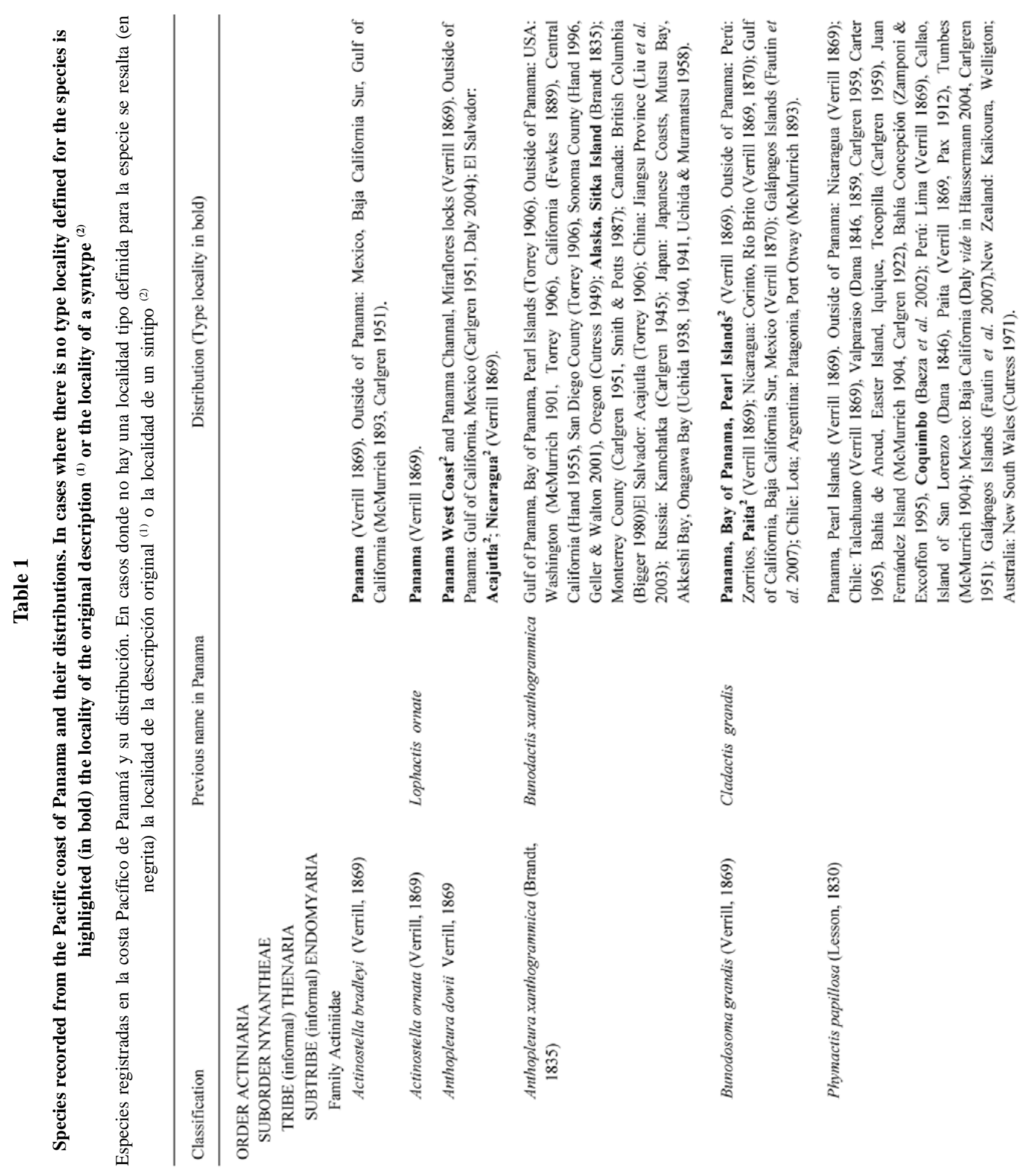



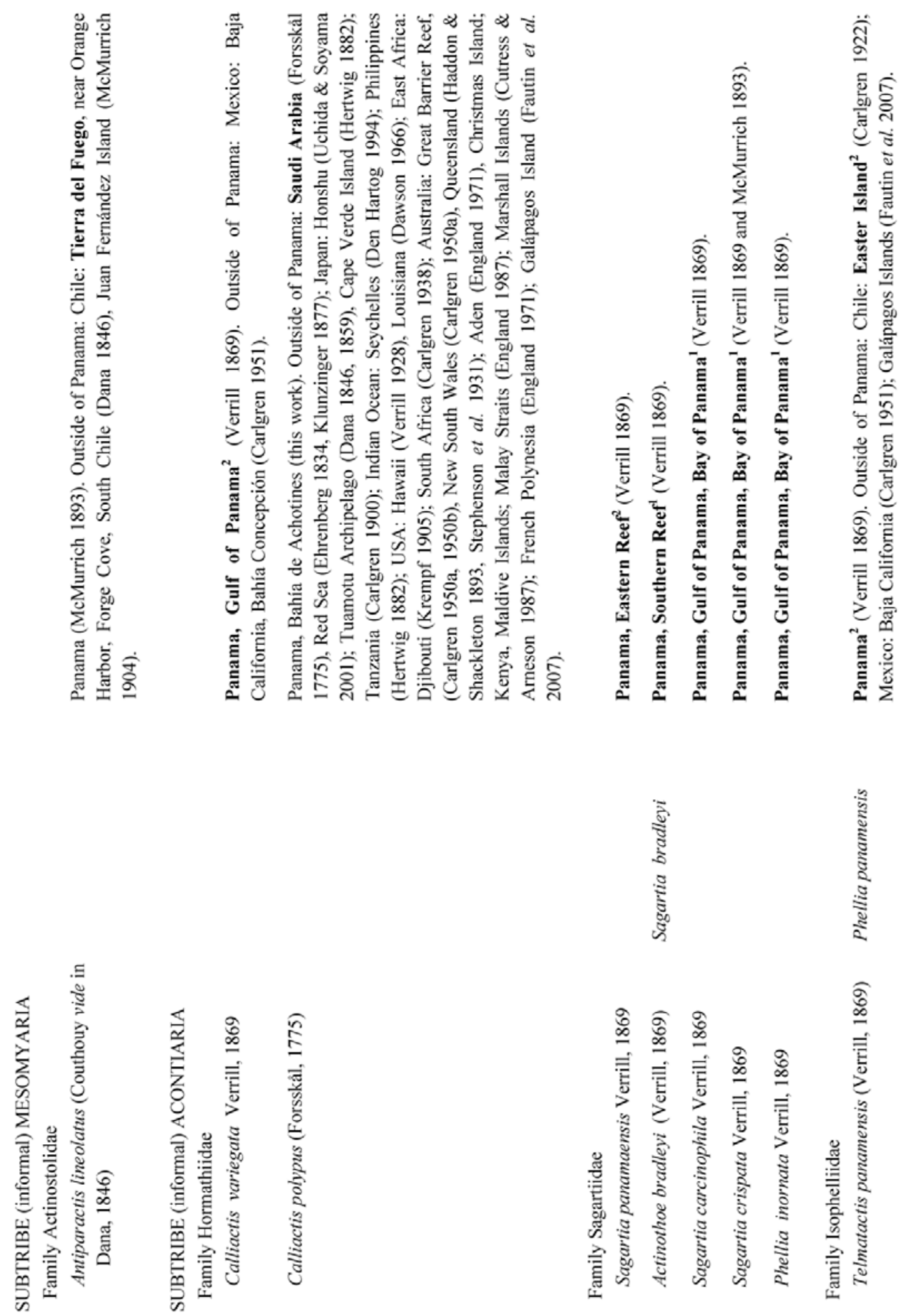

过 

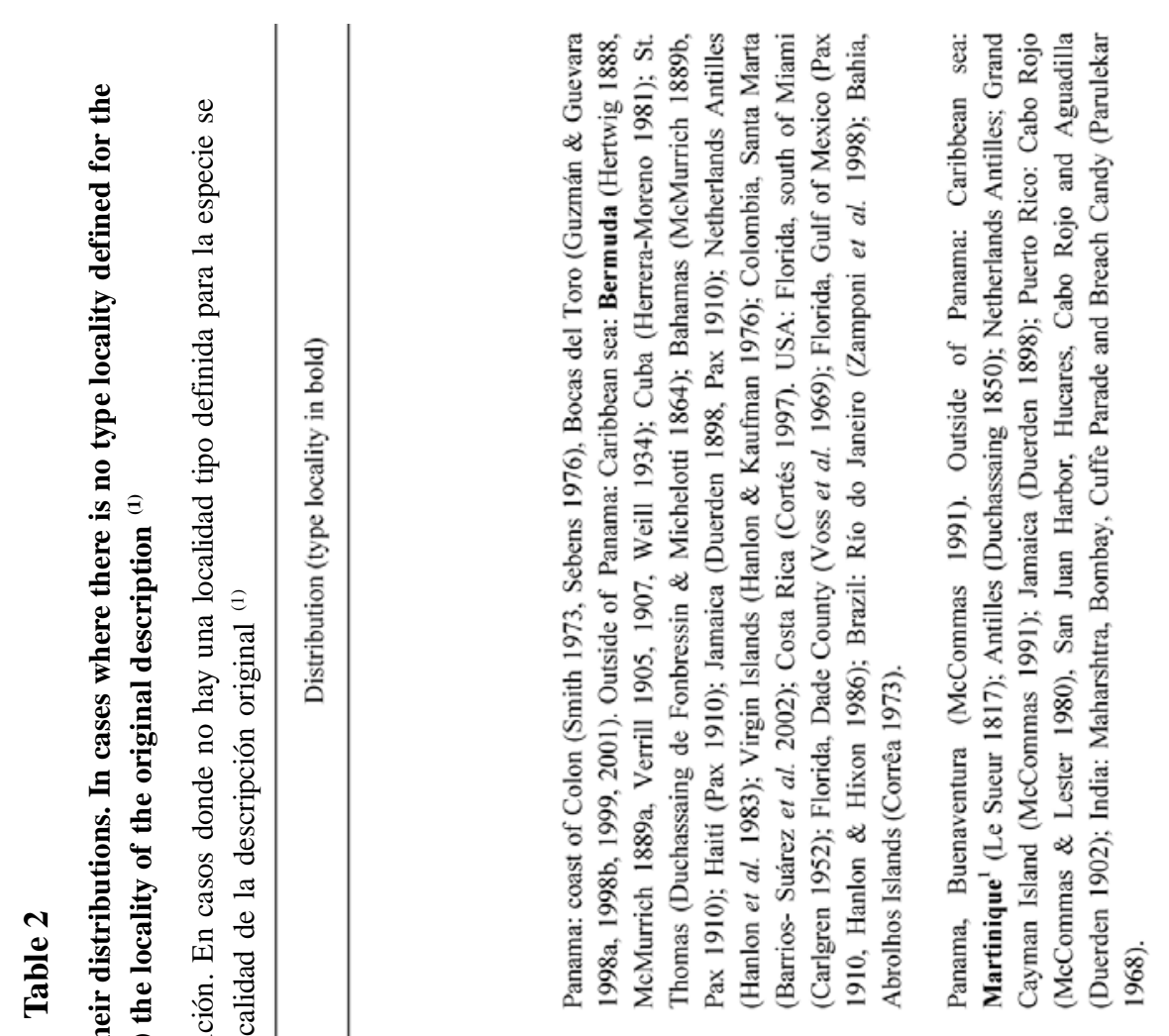

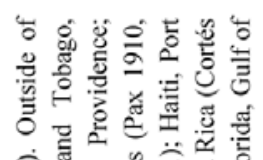

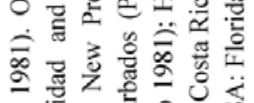

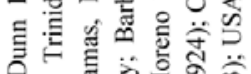

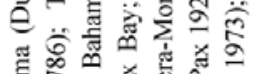

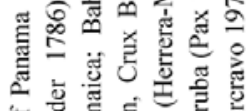

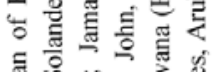

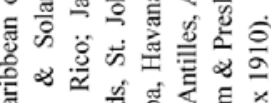

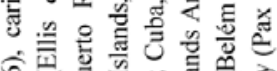

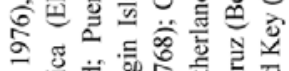

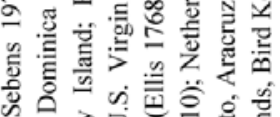

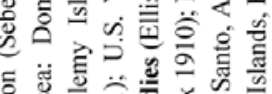

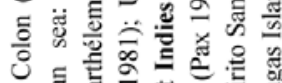

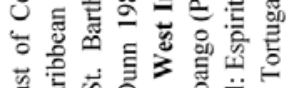

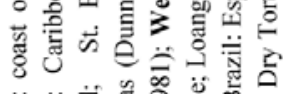

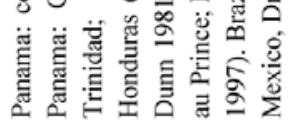

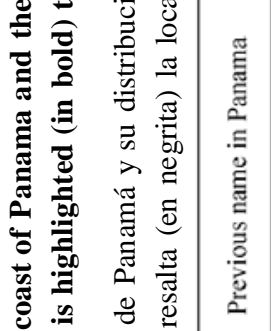

בั๊

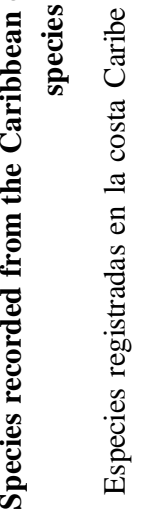

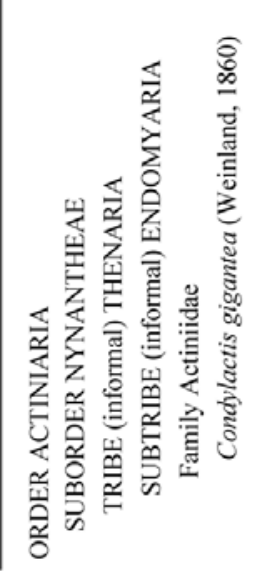

है

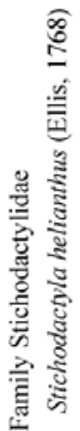



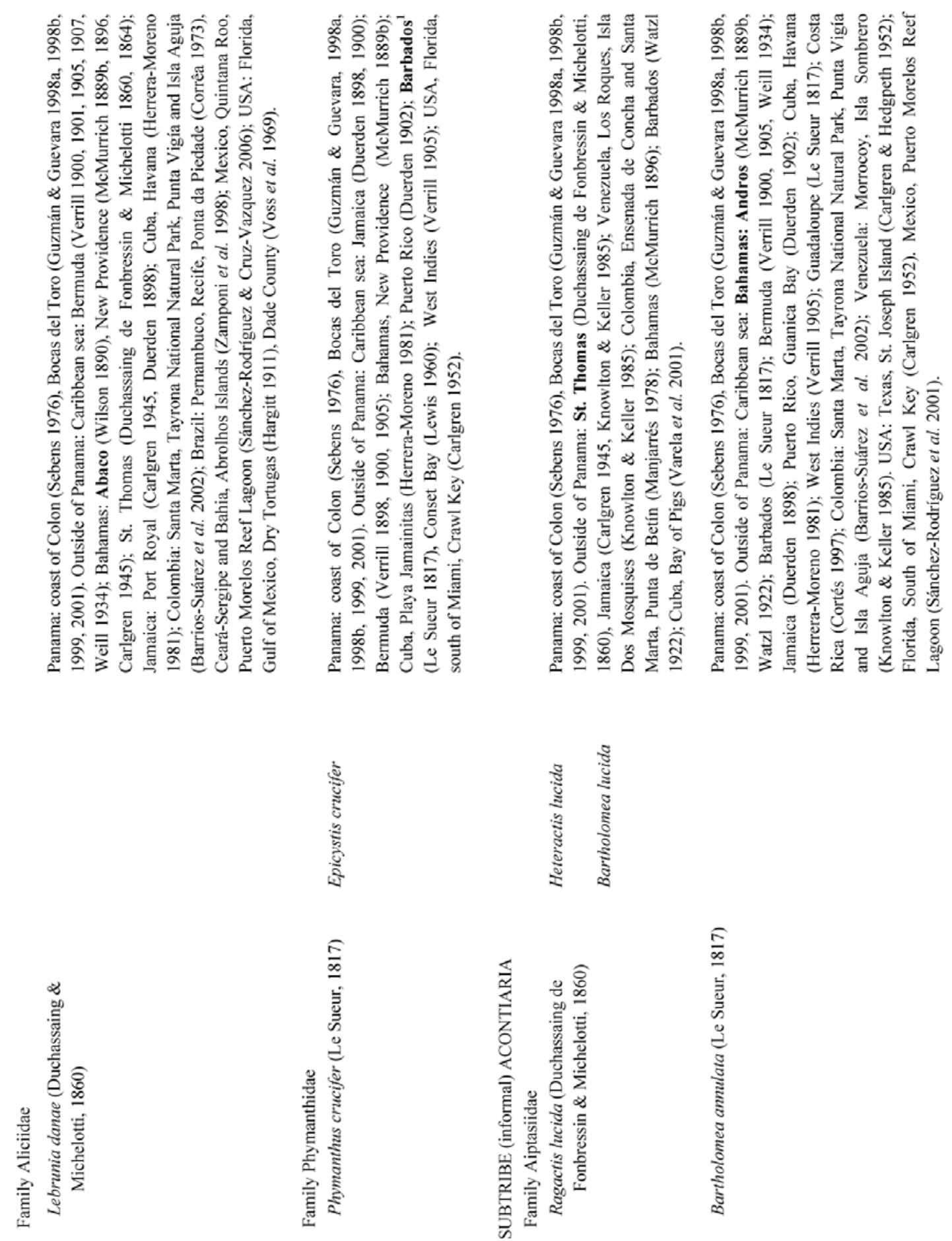

$\sim$
$\frac{0}{0}$
$\tilde{0}$
$\dot{0}$
$\dot{0}$ 


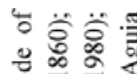

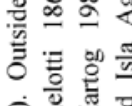

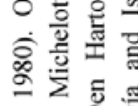
so

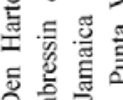

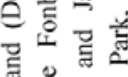

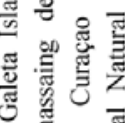

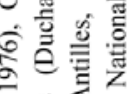

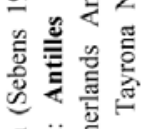

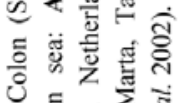

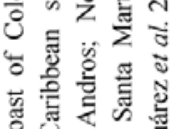

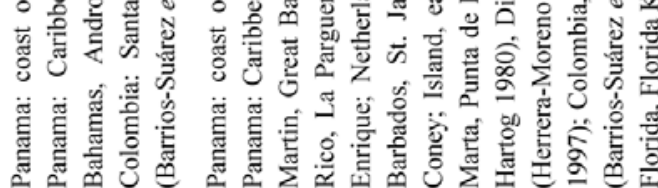

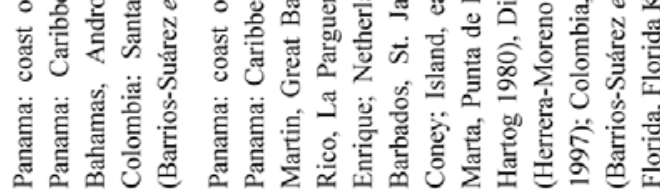

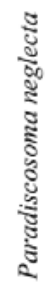

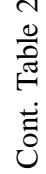

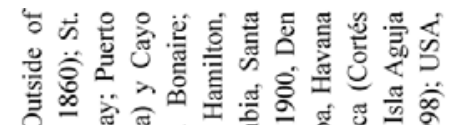

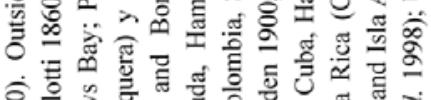

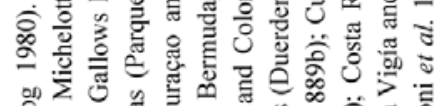

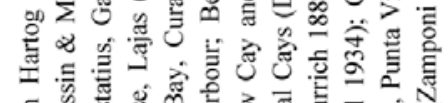

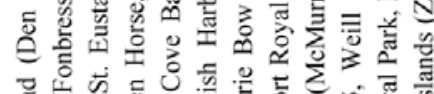

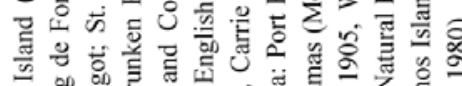

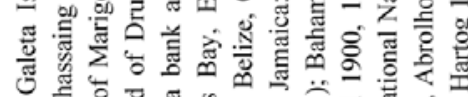

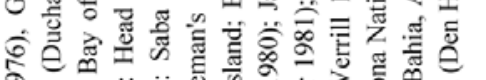

年

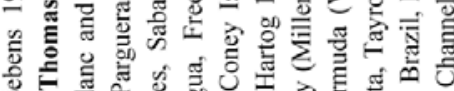

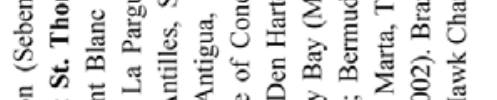

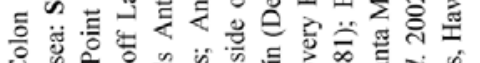

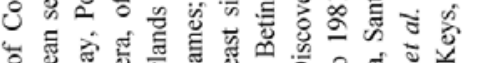

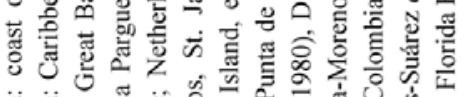

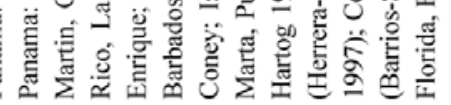

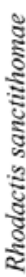

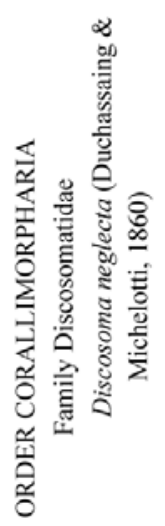

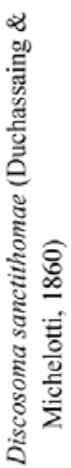

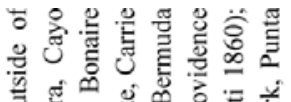

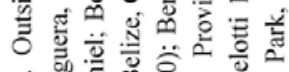

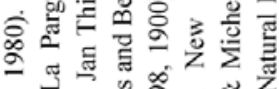

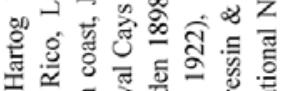

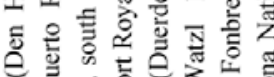

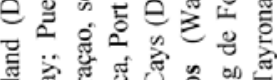

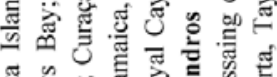

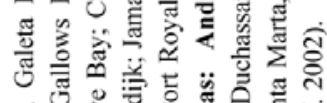

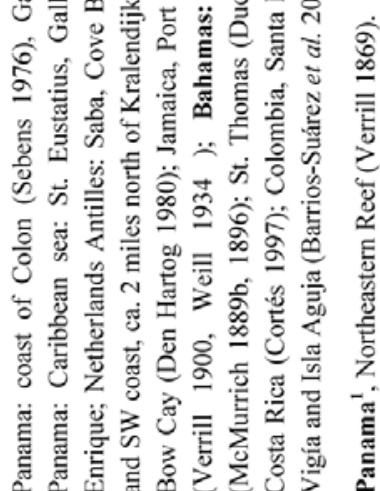

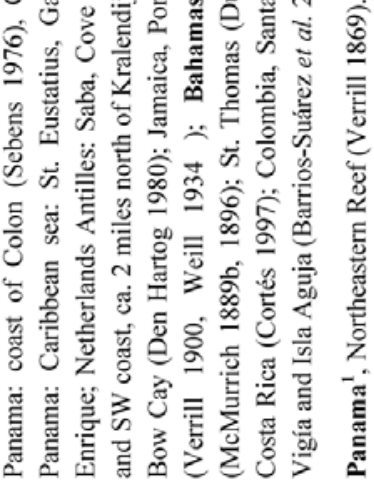

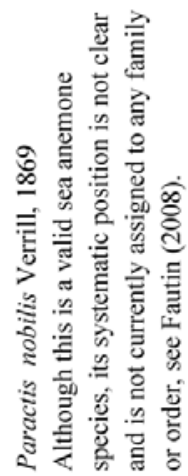




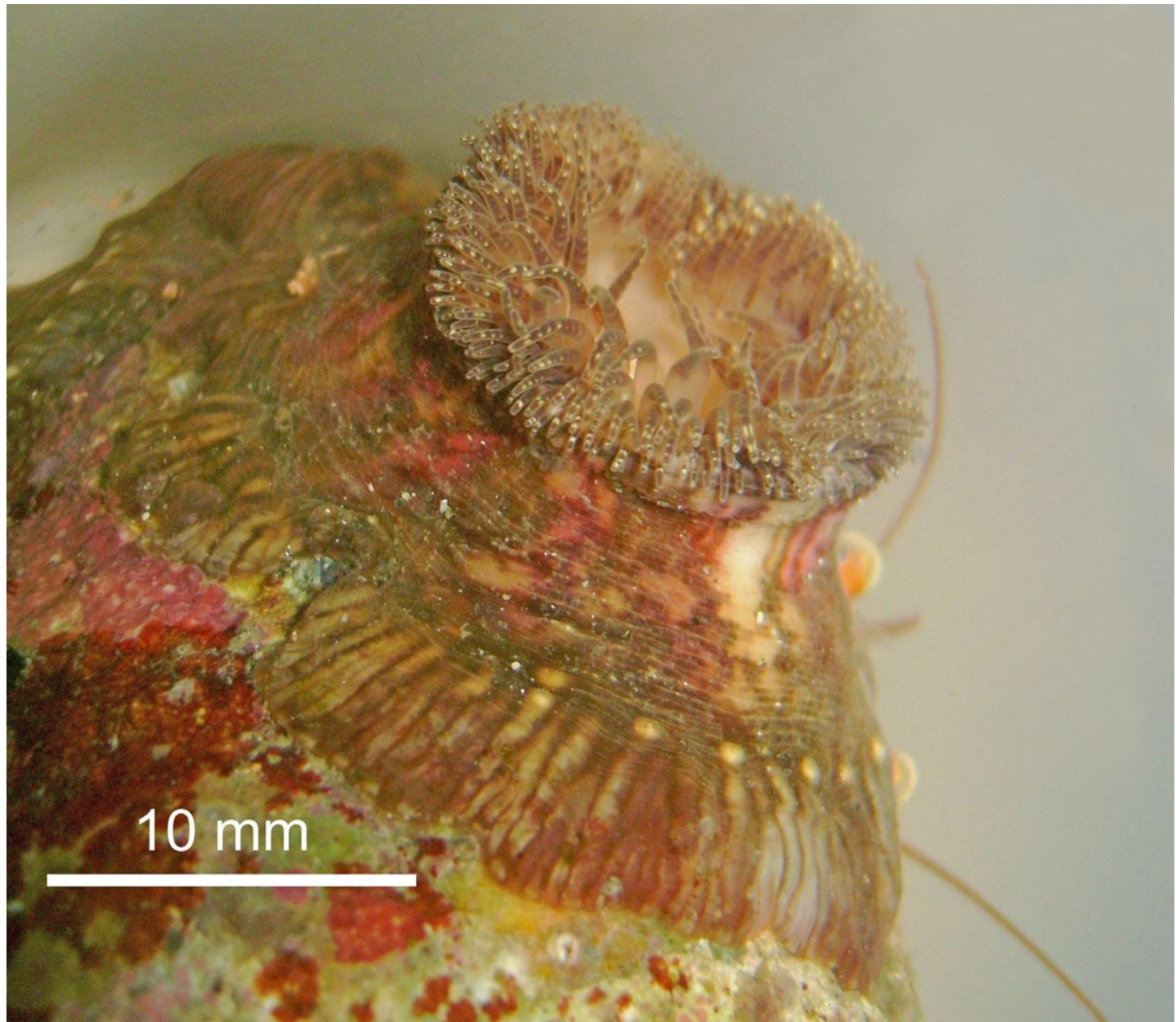

Figure 1

The sea anemone Calliactis polypus: A new record for Panama

La anémona de mar Calliactis polypus: un registro nuevo para Panamá

the Caribbean coast are concentrated in the region of Bocas del Toro, which is the site of the most recent records (Guzmán \& Guevara 1998a, 1998b, 1999, 2001).

Overall, existing records of sea anemones from Panama are strongly biased towards a few centers of high research activity (i.e. Gulf of Panama and Bocas del Toro), which indicates a pressing need for additional systematic collection of this group from under-represented areas.

We noted seven cases where the species have been described only from Panama, which represents approximately the $26 \%$ of the species. However, the richness of the sea anemone fauna in Panama is high in comparison to that of the neighboring countries Costa Rica and Colombia, probably because a poor knowledge due to a lower research effort in these countries. This shows that in general the actinian fauna of the area have been poorly studied. Further studies should be directed to explore under-represented areas and to search for new taxa or records but also in order to verify the descriptions and taxonomic status of recorded species.

\section{Acknowledgments}

We are grateful to Smithsonian Tropical Research Institute for granting A.G. an internship to visit Naos Island Laboratories (STRI, Panama). We thank Carlos Guevara and Catalina Gomez for logistical and field support. We are also grateful to three anonymous reviewers who helped to improve this manuscript. 


\section{Literature cited}

Baeza JA, WB Stotz \& ME Thiel. 2002. The agonistic behaviour and development of territoriality during ontogeny of the sea anemone dwelling crab Allopetrolisthes spinifrons (H. Milne Edwards, 1837) (Decapoda: Anomura: Porcellanidae). Marine and Freshwater Behaviour and Physiology 35(4): 189-202.

Barrios-Suárez LM, JO Reyes, GR Navas \& CB García. 2002. Distribución de las anémonas (Anthozoa: Actiniaria y Corallimorpharia) en el área de Santa Marta, Caribe colombiano. Ciencias Marinas 28(1): 37-48.

Belém MJC \& JC Preslercravo. 1973. Contribuições ao conhecimento da fauna de cnidários do Espírito Santo, Brasil I- Consideraçöes sobre Actiniária do Município de Aracruz, ES. Boletim do Museu de Biologia Prof. Mello Leitão, Zoologia 80(1): 1-14.

Bigger CH. 1980. Interespecific acrorhagial aggressive behavior among sea anemones: a recognition of self and not-self. The Biological Bulletin 159: 117-134.

Brandt JF. 1835. Prodromus descriptionis animalium ab $\mathrm{H}$. Mertensio in orbis terrarum circumnavigatione observatorum, 75 pp. Sumptibus Academiae, Petropoli, Saint Petersburg.

Carlgren O. 1900. Ostafrikanische Actinien. Gesammelt von Hern Dr. F. Stuhlmann 1888 und 1889. Mitteilungen aus dem Naturhistorinchen Museum in Hamburg 17: 21-144.

Carlgren O. 1922. Actiniaria und Zoantharia von Juan Fernandez und der Osterinsel. In: Skottsberg C (ed). The natural history of Juan Fernandez and Easter Island, pp. 145-160. Almqvist \& Wiksells Boktryckeri, Uppsala.

Carlgren O. 1938. South African Actiniaria and Zoantharia. Kungliga Svenska Vetenskapsakademiens Handlingar 17: $1-148$.

Carlgren O. 1945. Further contributions to the knowledge of the cnidom in the Anthozoa especially in the Actiniaria. Kungliga Fysiografiska Sällskapets Handlingar 56(9): 124.

Carlgren O. 1950a. Corallimorpharia, Actiniaria and Zoantharia from New South Wales and South Queenslands. Arkiv für Zoologi 10: 131-146.

Carlgren O. 1950b. Actiniaria and Corallimorpharia. Scientific Reports of the Great Barrier Reef Expedition 1928-29 5(7): 427-457.

Carlgren O. 1951. The actinian fauna of the Gulf of California. Proceedings of the United States National Museum 101(3282): 415-449.

Carlgren O. 1952. Actiniaria from North America. Arkiv für Zoologi 3(30): 373-390.

Carlgren O. 1959. Reports from the Lund University Chile Expedition 1948-1949 38. Corallimorpharia and Actiniaria with description of a new genus and species from Peru. Arkiv für Zoologi 71(6): 1-38.
Carlgren O \& JW Hedgpeth. 1952. Actiniaria, Zoantharia and Ceriantharia from shallow water in the northwestern Gulf of Mexico. Publications of the Institute of Marine Science, University of Texas 2(2): 143-172.

Carter D. 1965. Actinias de Montemar, Valparaíso. Revista de Biología Marina 12: 129-157.

Corrêa DD. 1973. Sobre anêmonas-do-mar (Actiniaria) do Brasil. Boletim de Zoologia e Biologia Marinha 30: 457 468.

Cortés J. 1997. Biodiversidad marina de Costa Rica: Filo Cnidaria. Revista de Biología Tropical 44(3)/45(1): 323 334.

Cutress CE. 1949. The Oregon shore anemones (Anthozoa). Thesis Oregon State College, Corvallis, 57 pp.

Cutress CE. 1971. Corallimorpharia, Actiniaria and Zoanthidea. Memoirs of the National Museum of Victoria (Melbourne) 32: 83-92.

Cutress CE \& CA Arneson. 1987. Sea anemones of Enewetak Atoll. In: Devaney DM, ES Reese, BL Burch \& P Helfrich (eds). The natural history of Enewetak Atoll, pp. 53-62. Office of Scientific and Technical Information, U.S. Department of Energy, Washington.

Daly M. 2004. Anatomy and taxonomy of three species of sea anemones (Cnidaria: Anthozoa: Actiniidae) from the Gulf of California, including Isoaulactinia hespervolita Daly, n. sp. Pacific Science 58(3): 377-390.

Dana JD. 1846. Zoophytes. Volume VII of the United States Exploring Expedition during the years 1838, 1839, 1840, 1841, 1842. Under the command of Charles Wilkes, U.S.N, 740 pp. Lea and Blanchard, Philadelphia.

Dana JD. 1859. Synopsis of the report on zoophytes of the U.S. Exploring Expedition around the world, under C. Wilkes, U.S.N. commander, in the years 1838-1842, 172 pp. James D. Dana, New Haven.

Dawson CE. 1966. Additions to the known marine fauna of Grand Isle, Louisiana. Proceedings of the Louisiana Academy of Sciences 29: 175-180.

Den Hartog JC. 1980. Caribbean shallow water Corallimorpharia. Zoologische Verhandelingen 176: 1-83.

Den Hartog JC. 1994. Sea anemones of the Seychelles. In: Van der Land J (ed). Oceanic reefs of the Seychelles, pp 75-79. National Museum of Natural History, Leiden.

Duchassaing P. 1850. Animaux radiaires des Antilles, 33 pp. Plon Frêres, Paris.

Duchassaing de Fonbressin P \& G Michelotti. 1860. Mémoire sur les coralliaires des Antilles, 89 pp. Imprimerie Royale, Turin.

Duchassaing de Fonbressin P \& G Michelotti. 1864. Supplément au mémoire sur les coralliaires des Antilles, 112 pp. Imprimerie Royale, Turin.

Duerden JE. 1898. The Actiniaria around Jamaica. Journal of the Institute of Jamaica 2: 449-465. 
Duerden JE. 1900. Jamaican Actiniaria. Part II. Stichodactylinae and Zoantheae. Scientific Transactions of the Royal Dublin Society 7: 133-208.

Duerden JE. 1902. Report of the actinians of Porto Rico. Bulletin of the United States Fisheries Commission 20(2): 321-374.

Dunn DF. 1981. The clownfish sea anemones: Stichodactylidae (Coelenterata: Actiniaria) and other sea anemones symbiotic with Pomacentrid fishes. Transactions of the American Philosophical Society 71(1): 1-115.

Ellis J. 1768. An account of the Actinia sociata, or clustered animal-flower, lately found on the sea-coasts of the newceded islands. Philosophical Transactions of the Royal Society of London 57(2): 428-437.

Ellis J \& D Solander. 1786. The natural history of many curious and uncommon zoophytes, collected from various parts of the globe, 206 pp. Benjamin White and Son, London.

England KW. 1971. Actiniaria from Mururoa Atoll Tuamotu, Polynesia (Hormathiidae; Calliactis polypus Sagartiidae: Verrillactis n. gen paguri). Cahiers du Pacifique 15: 2339.

England KW. 1987. Certain Actiniaria (Cnidaria, Anthozoa) from the Red Sea and Tropical Indo-Pacific Ocean. Bulletin of the British Museum (Natural History), Zoology 53: 205292.

Ehrenberg CE. 1834. Beiträge zur physiologischen Kenntniss, der Corallenthiere im allgemeinen, und besonders des rothen Meers, nebst einem Versuche zur physiologischen systematik derselben. Abhandlungen der Königlichen Akademie der Wissenschaften zu Berlin 1: 225-380.

Fautin DG. 2008. Hexacorallians of the World. [on-line] <http:/ /geoportal.kgs.ku.edu/hexacoral/anemone2/index.cfm>

Fautin DG, CP Hickman Jr, M Daly \& T Molodtsova. 2007. Shallow-water sea anemones (Cnidaria: Anthozoa: Actiniaria) and tube anemones (Cnidaria: Anthozoa: Ceriantharia) of the Galápagos Islands. Pacific Science 61(4): 549-573

Fewkes JW. 1889. New invertebrata from the coast of California, 50 pp. J. Walter Fewkes, Boston.

Forsskål P. 1775. Descriptiones animalium avium, amphibiorum, piscium, insectorum, vermium; quae in itinere orientali observait, 164 pp. Mölleri, Havniae.

Geller JB \& ED Walton. 2001. Breaking up and getting together: evolution of symbiosis and cloning by fission in sea anemones (genus Anthopleura). Evolution 55(9): 17811794.

Guzmán HM \& CA Guevara. 1998a. Arrecifes coralinos de Bocas del Toro, Panamá: I. Distribución, estructura y estado de conservación de los arrecifes continentales de la Laguna de Chiriquí y la Bahía Almirante. Revista de Biología Tropical 46(3): 601-623.

Guzmán HM \& CA Guevara. 1998b. Arrecifes coralinos de Bocas del Toro, Panamá: II. Distribución, estructura y estado de conservación de los arrecifes de las Islas Bastimentos, Solarte, Carenero y Colón. Revista de Biología Tropical 46(4): 893-916.

Guzmán HM \& CA Guevara. 1999. Arrecifes coralinos de Bocas del Toro, Panamá: III. Distribución, estructura y estado de conservación de los arrecifes de las islas Pastores, Cristóbal, Popa y Cayo Agua. Revista de Biología Tropical 47: 659-675.

Guzmán HM \& CA Guevara. 2001. Arrecifes coralinos de Bocas del Toro, Panamá: IV. Distribución, estructura y estado de conservación de los arrecifes continentales de Península Valiente. Revista de Biología Tropical 49: 5366.

Haddon AC \& AM Shackleton. 1893. Description of some new species of Actiniaria from Torres Straits. Scientific Proceedings of the Royal Dublin Society 8(1): 116-131. Agregado en Calliactis polypus, tabla 1

Hand C. 1955. The sea anemones of central California Part II. The endomyarian and mesomyarian anemones. Wasmann Journal of Biology 13(1): 37-99.

Hand C. 1996. The alarm response and some predators of the sea anemone Anthopleura xanthogrammica (Brandt). The Wasmann Journal of Biology 51(1-2): 9-23.

Hanlon RT \& RF Hixon. 1986. Behavioral associations of coral reef fishes with the sea anemone Condylactis gigantea in the Dry Tortugas, Florida. Bulletin of Marine Science 39: $130-134$

Hanlon RT \& L Kaufman. 1976. Associations of seven West Indian reef fishes with sea anemones. Bulletin of Marine Science 26: 225-232.

Hanlon RT, RF Hixon \& DG Smith. 1983. Behavioral associations of seven West Indian reef fishes with sea anemones at Bonaire, Netherlands Antilles. Bulletin of Marine Science 33: 928-934.

Hargitt CW. 1911. Cradactis variabilis: an apparently new Tortugan actinian. Papers from the Tortugas Laboratory of the Carnegie Institution of Washington 3: 51-53.

Häussermann V. 2004. Re-description of Phymactis papillosa (Lesson, 1830) and Phymanthea pluvia (Drayton in Dana, 1846) (Cnidaria: Anthozoa), two common actiniid sea anemones from the south east Pacific with a discussion of related genera. Zoologische Mededelingen, Leiden 78: 345381.

Herrera-Moreno A. 1981. Nuevos registros de anémonas (Coelenterata: Actiniaria y Corallimorpharia) para aguas cubanas. Poeyana 214: 1-3.

Hertwig R. 1882. Die Actinien der Challenger-Expedition, 120 pp. Gustav Fisher, Jena.

Hertwig R. 1888. Report on the Actiniaria dredged by H.M.S. Challenger during the years 1873-1876 [Supplement]. Report on the Scientific Results of the Voyage of the H.M.S Challenger during the years 1873-76, Zoology 26(3): 156. 
Klunzinger CB. 1877. Die Korallthiere des Rothen Meeres. 1: Die Alcyonarien und Malacodermen, 98 pp. Gutmann'schen Buchhandlung, Berlin.

Knowlton N \& BD Keller. 1985. Two more sibling species of alpheid shrimps associated with the Caribbean sea anemones Bartholomea annulata and Heteractis lucida. Bulletin of Marine Science 37(3): 893-904.

Krempf A. 1905. Liste des Hexanthides rapportés de l'Océan Indien (Golfe de Tadjourah) par M. Ch. Graver. Bulletin du Muséum National d'Histoire Naturelle (Paris) 11: 191196.

Le Sueur CA. 1817. Observations on several species of the genus Actinia; illustrated by figures. Journal of the Academy of Sciences of Philadelphia 1: 149-154,169-189.

Lewis JB. 1960. The fauna of rocky shores of Barbados, West Indies. Canadian Journal of Zoology 38: 391-435.

Liu CM, XQ Wang, ZJ Feng \& ZM Lian. 2003. Diversity and biomass of sea anemones in the rocky intertidal zone of the Lianyun Harbor. Chinese Journal of Zoology 38(2): $47-50$

Manjarrés G. 1978. Nuevos encuentros de actinias (Hexacorallia) en la región de Santa Marta, Colombia. Anales del Instituto de Investigación Marina (Punta Betín) 10: 127-132.

McCommas SA. 1991. Relationships within the family Actiniidae (Cnidaria, Actiniaria) based on molecular characters. Hydrobiologia 216/217: 509-512.

McCommas SA \& LJ Lester. 1980. Electrophoretic evaluation of the taxonomic status of two species of sea-anemone. Biochemical Systematics and Ecology 8(3): 289-292.

McMurrich JP. 1889a. A contribution to the actinology of the Bermudas. Proceedings of the Academy of Natural Sciences of Philadelphia 1889: 102-126.

McMurrich JP. 1889b. The Actiniaria of the Bahamas Islands, W. I. Journal of Morphology 3(1): 1-80.

McMurrich JP. 1893. Report of the Actiniae collected by the United States Fish Commission Steamer Albatross during the winter of 1887-1888. Proceedings of the United States National Museum 16(930): 119-216.

McMurrich JP. 1896. Notes on some actinians from the Bahamas Islands, collected by the late Dr. J. I. Northrop. Annals of the New York Academy of Sciences 9: 181-194.

McMurrich JP. 1901. Report on the Hexactiniae of the Columbia University Expedition to Puget Sound during the summer of 1896. Annals of the New York Academy of Sciences 14(1): 1-52.

McMurrich JP. 1904. The Actiniae of the Plate collection. Zoologische Jahrbücher 6(Suppl. 2): 215-306.

Miller AC. 1981. Cnidarian prey of the snails Coralliophila abbreviata and C. caribaea (Gastropoda: Muricidae) in Discovery Bay, Jamaica. Bulletin of Marine Science 31(4): 932-934.
Parulekar A. 1968. Sea anemones (Actiniaria) of Bombay. Journal of the Bombay Natural History Society 65(1): 138147.

Pax F. 1910. Studien an westindischen Actinien. Zoologische Jahrbücher Suppl. 11(2): 157-330.

Pax F. 1912. Les actinies de la côte du Pérou recueillies par le Dr. P. Rivet. In: Service Géographique de l'Armée (ed). Mission du Service Géographique de l'Armée pour la mesure d'un Arc de Méridien Equatorial en Amérique du Sud sous le contrôle scientifique de l'Académie des Sciences 9: 1-28. Gauthier-Villars, Imprimeur-Libraire, Paris.

Pax F. 1924. Anthozoen des Leidener Museums. Zoologische Mededelingen, Leiden 8(1): 1-17.

Ritson-Williams R \& VJ Paul. 2007. Periclimenes yucatanicus and Periclimenes rathbunae on unusual corallimorph hosts. Coral Reefs 26: 147 <doi: 10.1007/s00338-006-0178-6>

Sánchez-Rodríguez J \& K Cruz-Vazquez. 2006. Isolation and biological characterization of neurotoxic compounds from the sea anemone Lebrunia danae (Duchassaing and Michelotti, 1860). Archives of Toxicology 80: 436-441.

Sánchez-Rodríguez J, A Zugasti-Cruz \& JW Burnett. 2001. Cutaneous stings from Bartholomea annulata. Contact Dermatitis 44: 314-315.

Sebens KP. 1976. The ecology of Caribbean sea anemones in Panama: utilization of space on a coral reef. In: Mackie GO (ed). Coelenterate ecology and behavior. pp. 67-77. Plenun Press, New York.

Smith BL \& DC Potts. 1987. Clonal and solitary anemones (Anthopleura) of western North America: population genetics and systematics. Marine Biology 94: 537-546.

Smith WL. 1973. Record of a fish associated with a Caribbean Sea Anemone. Copeia 1973(3): 597-598.

Stephenson TA, A Stephenson \& G Tandy. 1931. The ecology of Low Isles. Scientific Reports of the Great Barrier Reef Expedition 1928-29 3(2): 35-68.

Torrey HB. 1906. The California shore anemone, Bunodactis xanthogrammica. University of California Publications in Zoology 3(3): 41-45.

Uchida T. 1938. Report of the biological survey of Mutsu Bay 33. Actiniaria of Mutsu Bay. Science Reports of the Tohoku Imperial University, Serie 4 Biology 13(3): 281-317.

Uchida T. 1940. The fauna of Akkeshi Bay. 10. Actiniaria. Journal of the Faculty of Science, Hokkaido University, Serie 6, Zoology 7(3): 265-275.

Uchida T. 1941. Actiniaria collected in the vicinity of Onagawa Bay. Science Reports of the Tohoku Imperial University. Serie 4. Biology 16: 383-390.

Uchida T \& S Muramatsu. 1958. Notes of some Japanese sea-anemones. Journal of the Faculty of Science, Hokkaido University, Serie 6. Zoology 14(1): 111-119. 
Uchida H \& I Soyama. 2001. Sea anemones in Japanese waters, 157 pp. TBS Britannica, Tokyo.

Varela C, I Santana, M Ortiz, R Lalana, H Caballero \& P Chevalier. 2001. Adiciones a la actinofauna (Anthozoa: Actiniaria y Corallimorpharia) de Cuba. Revista de Investigaciones Marinas 22(3): 187-190.

Verrill AE. 1869. Review of the corals and polyps of the west coast of America. Transactions of the Connecticut Academy of Arts and Sciences 1(6): 374-558.

Verrill AE. 1870. On the geographical distribution of the polyps of the west coast of America. Transactions of the Connecticut Academy of Arts and Sciences 1(7): 558-567.

Verrill AE. 1898. Descriptions of new American actinians, with critical notes on other species, I. American Journal of Science and Arts 6(156): 493-498.

Verrill AE. 1900. Additions to the Anthozoa and Hydrozoa of the Bermudas. Anthozoa. Transactions of the Connecticut Academy of Arts and Sciences 10(2): 551-572.

Verrill AE. 1901. Additions to the fauna of the Bermudas from the Yale Expedition of 1901, with notes on other species. Transactions of the Connecticut Academy of Arts and Sciences 11(1): 15-62.

Verrill AE. 1905. The Bermuda Islands. Part IV. Geology and paleontology, and Part. V. An account of the coral reefs. Transactions of the Connecticut Academy of Arts and Sciences 12: 45-348.
Verrill AE. 1907. Zoology of Bermuda, pp. 15-62. AE Verrill, New Haven.

Verrill AE. 1928. Hawaiian shallow water Anthozoa. Bernice P. Bishop Museum Bulletin 49: 3-30.

Voss GL, FM Bayer, CR Robins, M Gomon \& ET LaRoe. 1969. The marine ecology of the Biscayne National Monument, 128 pp. University of Miami, Miami.

Watzl O. 1922. Die Actiniarien der Bahamainseln. Arkiv für Zoologi 14(24): 1-89.

Weill R. 1934. Contribution a l'Étude des Cnidaires et de leurs Nématocystes. Travaux. Station Marine de Wimereux 10/ 11: $1-701$

Wilson HV. 1890. On a new actinia, Hoplophoria coralligens. Studies at the Biological Laboratory of the Johns Hopkins University (Baltimore) 4(6): 379-387.

Zamponi MO \& AC Excoffon. 1995. La anemonofauna de Bahía Concepción (Chile). I. Algunos aportes a la distribución y biología de los géneros Phlyctenactis Stuckey, 1909 (Actiniaria: Actiniidae) y Antholoba Hertwig, 1882 (Actiniaria: Actinostolidae). Physis 50A (118-119): 1-6.

Zamponi MO, MJC Belém, E Schlenz \& FH Acuña. 1998. Distribution and some ecological aspects of Corallimorpharia and Actiniaria from shallow waters of the South American Atlantic coasts. Physis 55: 31-45.

Recibido el 5 de mayo de 2009 y aceptado el 23 de septiembre de 2009 